DOI

\title{
ВПЛИВ ГОСТРОГО СТРЕСУ НА ПОКАЗНИКИ ЖОВЧОВИДІЛЬНОЇ ФУНКЦІЇ ПЕЧІНКИ В УМОВАХ КРІОУРАЖЕННЯ ШКІРИ В ЕКСПЕРИМЕНТІ
}

\author{
๑О. Б. Сван
}

\section{ДВНЗ «Тернопільський державний медичний університет імені І. Я. Горбачевського мОз України»}

РЕЗЮМЕ. В умовах кріодеструкції 10 \% поверхні шкіри через 3 і 7 діб спостереження у тварин, яким попередньо моделювали гострий стрес, відмічається більше порушення жовчовидільної функції печінки, ніж у нестресованих тварин. Після нанесення кріотравми швидкість жовчовиділення нормалізується до 28 доби, тоді як на тлі попереднього гострого стресу показник залишається вірогідно нижчим, ніж у контролі.

КЛЮчОВІ СЛОВА: кріодеструкція шкіри, гострий стрес, печінка, жовчовиділення.

Вступ. Основною проблемою тяжкої травми продовжує залишатися розвиток поліорганної недостатності [11]. Незважаючи на значні досягнення в їі своєчасній діагностиці і лікуванні смертність останнім часом залишається на стабільно високому рівні. Тому важливим напрямком сучасної теоретичної і практичної медицини є поглиблення вивчення патогенезу формування органної дисфункції і недостатності в умовах травми.

На сьогодні існують численні моделі тяжкої травми, які з біоетичних міркувань здебільшого наносять в умовах знеболювання лабораторних тварин [4]. Основним їх недоліком $\epsilon$ нехтування стресракцією, яка виникає в організмі у відповідь на травму. За даними ряду авторів, моделювання гострого стресу перед нанесенням травми істотно підвищує іï інформативність. Залежно від інтенсивності дії стресогенного чинника вдається домогтися підвищення резистентності організму в умовах травми і запобігти розвитку тяжкої поліорганної дисфункції [5] а6о значно поглибити розвиток основного патологічного процесу [10].

Відомо, що в умовах кріоураження шкіри виникають системні порушення, одним із проявів яких $\epsilon$ розвиток дистрофічно-некротичних змін з боку печінки [7]. У наших попередніх роботах було показано, що в цих умовах у печінці виникають значні функціональні порушення, які оцінювалися на основі вивчення жовчутворювальної і жовчовидільної функцій печінки, що належать до органоспецифічних і характеризуються значною інформативністю [2]. Однак вплив гострого стресу на функціональну здатність печінки в умовах кріоураження шкіри вивчений недостатньо.

Мета роботи - з'ясувати вплив гострого стресу на показники жовчовидільної функції печінки в умовах кріоураження шкіри в експерименті.

Матеріал і методи дослідження. Експерименти виконано на 60 нелінійних білих щурахсамцях масою 170-180 г. У першій дослідній групі виконували кріодеструкцію шкіри, у другій додатково моделювали моделювали гострий холодовий стрес. Контролем слугували інтактні тварини.

Дослідження проводили відповідно до санітарно-гігієнічних норм та принципів Європейської конвенції із захисту лабораторних тварин [13].

Локальну кріодеструкцію шкіри (10 \% від загальної площі) виконували в умовах знеболювання за методикою Gunas I. et al. (1997) [14]. Гострий холодовий стрес моделювали шляхом розміщення іммобілізованої тварини в холодильну камеру на 2 год при температурі $+4^{\circ} \mathrm{C}[6]$.

Функціональний стан печінки оцінювали за показниками жовчовиідльної функції печінки через 3, 7, 14, 21 і 28 діб експерименту. Під тіопентало-натрієвим знеболюванням (60 мг·кг $\left.{ }^{1}\right)$ у тварин катетеризували загальну жовчну протоку і проводили забір жовчі протягом 1 год. Розраховували швидкість жовчовиділення [3]. 3 експерименту тварин виводили швидкою декапітацією.

Отриманий цифровий матеріал обробляли методом варіаційної статистики з використанням критерію Стьюдента.

Результати й обговорення. Як видно з рисунка 1, після нанесення кріотравми швидкість жовчовиділення, порівняно із контрольною групою, суттєво знижувалася вже через 3 доби спостереження (на $27,8 \%, p<0,05$ ) і досягала мінімуму через 14 діб (на 44,7 \%, р<0,05). У цих експериментальних умовах показник ставав статистично вірогідно меншим, ніж через 3 доби (на 23,4 \%, $p<0,05$ ). В подальшому показник зростав, досягаючи рівня контрольної групи через 28 діб $(p>0,05)$. У цей термін спостереження він виявився статистично вірогідно більшим, ніж у всі попередні $(p<0,05)$.

У тварин, яким перед кріоураженням моделювали гострий стрес, через 3 і 7 діб інтенсивність зменшення жовчовидільної функції була більш вираженою. Порівняно із контрольною групою показник був відповідно на 40,7 і 52,1 \% меншим ( $<<0,05)$. В ці терміни спостереження він виявився також статистично вірогідно меншим, ніж у тварин без гострого стресу (відповідно на на 17,9 і 10,9\%, p<0,05). 
Огляди літератури, оригінальні дослідження, погляд на проблему

мл·год $-1 \cdot \mathrm{kr}^{1}$

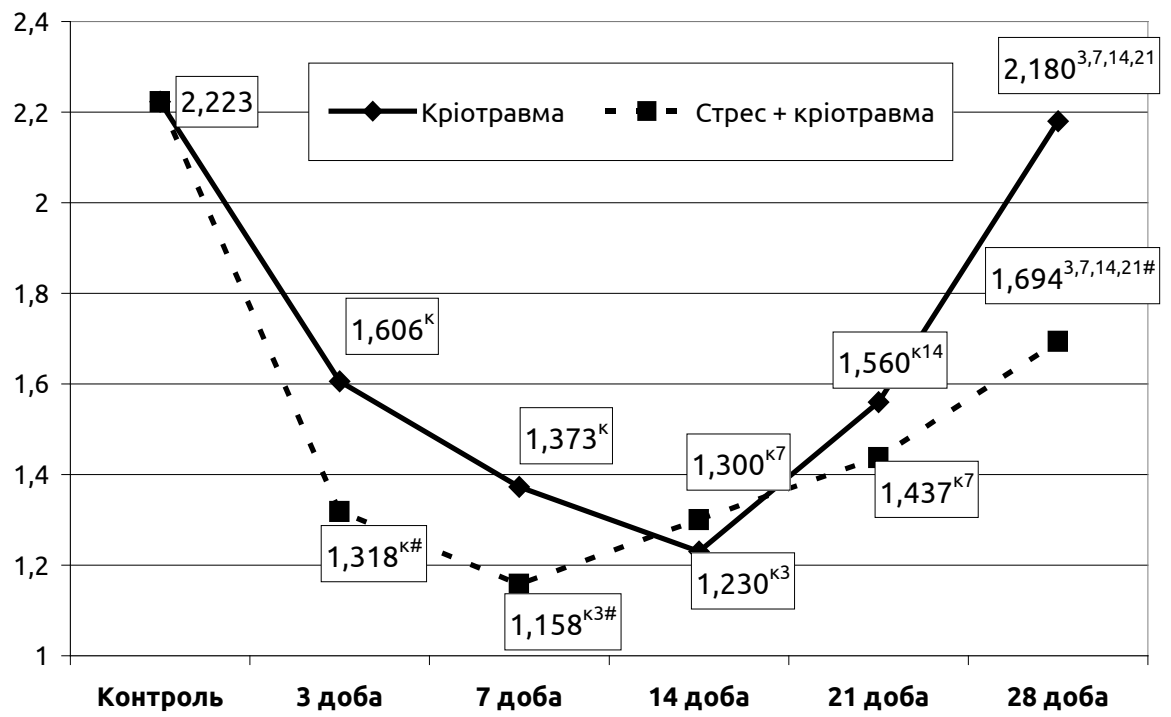

Рис. 1. Вплив гострого стресу на динаміку швидкості жовчовиділення на тлі кріотравми.

(Примітка: ${ }^{\text {}}$ - відмінності стосовно контрольної групи статистично вірогідні (р<0,05); ${ }^{3,7,14,21}$ - відмінності стосовно $3,7,14$ і 21 ді6 спостережень статистично вірогідні $(p<0,05) ;{ }^{\#-~ в і д м і н н о с т і ~ м і ж ~ с т р е с о в а н и м и ~ і ~ н е с т р е с о в а н и м и ~ т в а р и н а м и ~ с т а т и с т и ч н о ~ в і р о г і д н і ~}$ $(p<0,05))$.

В подальшому швидкість жовчовиділення зростала. Через 14 і 21 добу показник виявився істотно більшим, ніж через 7 діб (відповідно на 12,3 і 24,1\%, p<0,05). Через 28 діб показник ще більше зростав і статистично вірогідно перевищував усі попередні терміни спостереження $(p<0,05)$. В цей термін спостереження даний показник виявився статистично вірогідно меншим, ніж у групі тварин без гострого стресу - на 22,3\% $(p<0,01)$.

Таким чином, через 3 і 7 діб спостереження у тварин з кріодеструкцією шкіри і гострим стресом відмічається більш виражене порушення швидкості жовчовиділення. У тварин без гострого стресу досліджуваний показник нормалізується до 28 доби, тоді як у тварин з гострим стресом у цей термін спостереження він так і не досягає рівня контрольної групи. Можна припустити, що значне погіршення жовчовидільної функції печінки в ранній період травми зумовлене активацією ліпідної пероксидації, яка належить до провідних патогенних ланок гострого стресу [9]. За даними багатьох досліджень, активація вільнорадикального окиснення ліпідів при стресі призводить до пошкодження мембран гепатоцитів і розвитку гепатиту [12].

На тлі кріодеструкції шкіри попередній гострий стрес значно поглиблює порушення функ- ціонального стану печінки й у пізній період травми, що очевидно пов'язане із ефектом сумації системних патогенних механізмів гострого стресу і кріоураження. Цей термін травматичного процесу, як правило, зумовлений імунними порушеннями 3 розвитком вторинного імунодефіциту [4]. Як відомо, гострий стрес спричиняє суттєву імунну супресію, яка проявляється зменшенням продукції антитіл та фагоцитарної ланки імунної відповіді $[1,8]$. Очевидно, має місце виражена слідова реакція, зумовлена гострим стресом, що варто враховувати у клініці на етапі прогнозування результатів лікування постраждалих із тяжкою трамвою.

Висновок. 1. В умовах кріодеструкції $10 \%$ поверхні шкіри через 3 і 7 діб спостереження у тварин, яким попередньо моделювали гострий стрес, відмічається більше порушення жовчовидільної функції печінки, ніж у нестресованих тварин.

2. Після нанесення кріотравми швидкість жовчовиділення нормалізується до 28 доби, тоді як на тлі попереднього гострого стресу показник залишається вірогідно нижчим, ніж у контролі.

Перспективи подальших досліджень. Отримані результати ляжуть в основу досліджень стреспротективних засобів з метою профілактики поліорганної недостатності в умовах трамви. 


\section{ЛІТЕРАТУРА}

1. Галеев Ф. С. Взаимосвязь изменений гормонов гипоталамо-гипофизарно-надпочечниковой системы и щитовидной железы у различных по тяжести и исходу больных с тяжелой травмой / Ф. С. Галеев, Р. М. Габдулхаков // Девятый съезд Федерации анестезиологов и реаниматологов. - Иркутск, 2004. - С. 61-62.

2. Гудима А. А. Порушення морфофункціонального стану печінки в умовах локальної кріодеструкції шкіри та його корекція / А. А. Гудима, О. Б. Сван, Т. В. Дацко // Здобутки клінічної і експериментальної медицини. 2007. - № 2. - С. 183-188.

3. Доклінічні дослідження лікарських засобів : метод. рекоменд. / за ред. чл.-кор. АМН України О. В. Стефанова. - К. : Авіценна, 2001. - 528 с.

4. Ельский В. Н. Моделирование черепно-мозговой травмы / В. Н. Ельский, С. В. Зяблицев. - Донецк : Изд-во “Новый мир”, 2008. - 140 с.

5. Зятковська О. Я. Роль попереднього гострого емоційного стресу в перебігу комбінованої травми в експерименті / О. Я. Зятковська, А. А. Гудима // Актуальні проблеми транспортної медицини. - 2011. - № 1 (23). - С. 120-123.

6. Иммуномодулирующее действие препаратов витамина k и его усиление рибоксином при остром холодовом стрессе / Н. А. Быстрова, И. Л. Бровкина, Л. Г. Прокопенко, Б. С. Утешев // Экспериментальная и клиническая фармакология. - 2000. - № 5. - С. 50-53.

7. Маєвський О. Є. Ультраструктурні зміни в печінці щурів в різні терміни після кріодеструкції шкіри та на фоні попереднього введення мексидолу / О. Є. Маєвський // Вісник морфології. - 2003. - Т. 9, № 2. - С. 233-235.
8. Назаров И. П. Стресспротекция в хирургии повышенного риска / И. П. Назаров, Ю. А. Дыхно, Д. В. Островский. - Красноярск, 2003. - 374 с.

9. Некоторые показатели стресс-реакции организма на разных этапах постреанимационного периода / Е. А. Мутускина, Л. А. Багдасарова, И. Е. Трубина, Ю. В. Заржецкий // Бюллетень экспериментальной биологии и медицины. - 2002. - № 1. - С. 38-41.

10. Патент UA 45324 U MПK: G09B 23/00 Спосі6 моделювання політравми (Зятковська О. Я., Гудима А. А., Секела Т. Я., Сокольвак В. М.). - №u200903778. Заявлено 17.04.2009 р.; Опубл. 10.11.2009 р. Бюл. № 21.

11. Рощін Г. Г. Багатофакторний аналіз летальності при поєднаній травмі органів черевної порожнини / Г. Г. Рощін, В. І. Іванов, В. О. Крилюк // Клінічна хірургія. К. : ТОВ “Ліга-Інформ" - 2013. - № 4. - С. 40-44.

12. Структура печени у крыс в динамике иммобилизационного стресса / И. С. Выборова, У. Хаджав, Л. С. Васильева, Н. Г. Макарова // Сибирский медицинский журнал. -2005 . - № 3. - С. 31-35.

13. Europen convention for the protection of vertebrate animals used for experimental and other scientific purposes. - Strasbourg: Council of Europ. - 1986. № $123 .-\mathrm{P} .52$.

14. Gunas I. Method of thermal burn trauma correction by means of cryoinfluence / I. Gunas, I. Dovgan, O. Masur //Verhandlungen der Anatomischen Gesellschaft. 92. In Olsztyn vom 24. Bis 27. Mai 1997: bipartitemeeting / zusammen mit der Polish Anatomical Society with the participation of the Association des Anatomistes. - 1997. P. 105.

\section{INFLUENCE OF AN ACUTE STRESS ON INDICES OF BILIGENIC LIVER FUNCTION IN THE CONDITIONS OF SKIN CRYOLESION IN AN EXPERIMENT}

๑O. B. Svan

\section{SHEI «Ternopil State Medical University by I. Ya. Horbachevsky of MPH of Ukraine»}

SUMMARY. In terms of cryodestruction $10 \%$ of the surface of the skin after 3 and 7 days of observation in animals, which previously modeled acute stress observed more violations of biliary liver function than not stress animals. After causing bile criotrauma speed normalized to 28 days, while on the background of previous acute stress indicator remains significantly lower than in controls.

KEY WORDS: skin cryodestruction, acute stress, liver, biligenic. 